Buana Sains Vol 18 No 2: 149 - 160, 2018

\title{
UPAYA MENINGKATKAN PRODUKSI TANAMAN TOMAT DENGAN APLIKASI GANDASIL B
}

\author{
Astutik dan Astri Sumiati
}

Program Studi Agroteknologi, Fakultas Pertanian, Universitas Tribhuwana Tunggadewi

\begin{abstract}
One of efforts to increase tomato plant productions can be done by fertilization. Gandasil B was one of leaf fertilizer which can be used to fill P of plant so that it can increase the plant production. However, so far it has not been used for tomato plants. Therefore, it needs to do a research in order to find out the concentration and fertilization period of Gandasil B to tomato production. The research was conducted in Lowokwaru Village, Malang on March to August 2012. The research consisted of 8 treatment combinations, they are K0P1 (without treatment), K1P2 (1g/1 per 1 week), K2P1 (2g/1 per 1 week), K3P1 (3g/l per 1 week), K0P2 (without treatment), K1P2 (1g/1 per 2 weeks), K2P2 (2 g/l per 2 weeks), K3P2 (3 g/l per 2 weeks). Each treatment was repeated four times. The research results can be concluded that there is concenration interaction and fertilization period to plant height at the age of 14 and 49 days after planting, leaves amount at the age of 14, 21, 28, 35, and 42 after planting, flowers amount at the age of 49 days after planting, branches amount at the age of 49 days after planting, and fruits amount. However, partially fertilization period treatment affects at flowering time, flowers amount at the age of 28.35 and 42 days after planting, and fruits weight. The best plant of Gandasil B fertilization results 25.98 fruits/plant with total weight of $1.23 \mathrm{~kg} /$ plant
\end{abstract}

Keywords: Tomato; aplication; gandasil B; leave fertilizer; production.

\section{Pendahuluan}

penting dalam memenuhi gizi masyarakat. Masyarakat menggunakan tomat untuk masakan maupun minuman dalam kebutuhan sehari-hari. Buah tomat sangat bermanfaat bagi kesehatan manusia karena bernilai gizi yang sangat tinggi, seperti protein, karbohidrat, vitamin $A$, vitamin $B$, vitamin $C$, dan mineral. Kebutuhan mineral, vitamin A, dan vitamin $C$ setiap orang akan terpenuhi apabila setiap hari mengkonsumsi buah atau sayuran, khususnya tomat sebanyak 300-1000 g (Ichsan, 2001).

Tomat merupakan salah satu jenis tanaman hortikultura yang keberadaannya sering dimanfaatkan dan memiliki nilai ekonomi tinggi yang dapat digunakan sebagai sumber alternatif pendapatan petani (Cahyono, 2008). Hal ini ditunjang dengan permintaan pasar baik dalam negeri maupun luar negeri yang selalu mengalami peningkatan dari tahun ke tahun (Hanindita, 2008).

Permintaan pasar yang tinggi tidak diimbangi dengan produktifitas 
tomat yang tinggi pula (Purwati dan Khairunisa, 2007). Untuk meningkatkan hasil produksinya, pada umumnya petani menggunakan pupuk NPK (Cahyono, 2008). Akan tetapi bagi para petani pupuk ini masih tergolong sangat mahal (Astuti dan Robert, 2001). Selain itu, juga pupuk ini dapat memberikan dampak buruk bagi lingkungan yang berimbas pada rusaknya ekosistem yang dapat dilihat dari tingginya tingkat pencemaran air dan tanah (Cahyono, 2008)

Berdasarkan data dari Badan Pusat Statistik Sulawesi Tenggara (2009), produksi tomat pada tahun 2011 sebanyak 3.009 ton dengan luas panen seluas 40 ha, sementara untuk Desa Lapandewa pada tahun 2011 produksi tanaman tomat sebanyak 93,58 ton dengan luas panen sekitar 10,56 ha. Tomat dikonsumsi dalam bentuk segar atau berupa produk hasil olahan. Berkaitan dengan permintaan tomat oleh konsumen, untuk keperluan industri tomat, diperlukan bahan baku berupa tomat segar, seperti saus tomat yang memiliki peluang usaha yang dapat dikembangkan dan bernilai ekonomi tinggi, tetapi masih memerlukan penanganan yang serius terutama dalam hal peningkatan hasil dan kualitas buahnya. Berdasarkan Badan Pusat Statistika (BPS, 2012), produksi tomat mulai tahun 2000 sampai tahun 2010 relatif mengalami kenaikan karena jumlah permintaan yang semakin naik pula. Produksi yang meningkat didukung dengan meningkatnya luas lahan yang ditanami tomat. Akan tetapi produksi tomat hanya terpusat didaerah jawa saja sehingga apabila produksi didaerah jawa mengalami gangguan maka kebutuhan tomat masyarakat Indonesia akan terganggu. Tomat memiliki beberapa keunggulan antara lain memiliki rasa yang bervariasi (manis dan agak keasaman), kualitas hasilnya tinggi, unggul dalam produksi, tahan terhadap serangan hama dan penyakit tertentu (Anonim, 2008). Varietas betavila F1 merupakan tomat yang unggul dibandingkan dengan varietas lainnya, maka penelitian perlu diarahkan untuk meningkatkan hasil dan kualitas tomat dengan menanam varietasvarietas unggulnya. Kemampuan tomat untuk dapat menghasilkan buah sangat tergantung pada interaksi antara pertumbuhan tanaman dan kondisi lingkungannya. Faktor lain yang juga menyebabkan produksi tomat rendah adalah budidayanya yang belum tepat sehingga diharapkan dapat meningkatkan hasil dan kualitas tomat. Kesuburan tanah merupakan kemampuan atau kapasitas tanah untuk menyediakan unsur hara dalam jumlah cukup untuk mendukung pertumbuhan dan perkembangbiakan tanaman (Sutanto, 1998). Tercukupinya semua kebutuhan unsur hara tanaman akan menjamin pertumbuhan tanaman yang baik dan akan memberikan hasil yang maksimal (Rosmarkam dan Yuwono, 2002). Kekurangan salah satu unsur hara dapat mengganggu pertumbuhan tanaman. Unsur esensial seperti nitrogen $(\mathrm{N})$, pospat $(\mathrm{P})$, dan kalium $(\mathrm{K})$ dibutuhkan tanaman tomat dalam jumlah yang cukup banyak. Apabila ketersediaan unsurunsur tersebut terbatas, maka perlu ditambahkan melalui pemupukan.

Pemupukan yang dilakukan petani masih kurang tepat, pupuk belum digunakan secara rasional dan berimbang karena tidak didasari pada status hara tanah dan sesuai dengan kebutuhan tanaman. Pemupukan belum didasarkan atas hasil uji tanah, sehingga akan memberikan dampak yang kurang menguntungkan bagi sifat tanah dan lingkungan secara keseluruhan (Sabiham, 1996). Pupuk anorganik atau pupuk buatan adalah jenis pupuk yang dibuat oleh pabrik dengan cara meramu 
berbagai bahan kimia sehingga memiliki persentase kandungan hara yang tinggi dan berimbang (Novizan, 2002). Salah satu jenis pupuk anorganik adalah pupuk daun. Setiap jenis pupuk daun tersebut mempunyai kelebihan dan kekurangan masing-masing sehingga diperlukan informasi mengenai jenis pupuk yang paling sesuai untuk memenuhi kebutuhan tanaman tomat.

Pupuk daun Gandasil B mengandung N $6 \%$, P $20 \%, \mathrm{~K} 30 \%$, dan $\mathrm{Mg} 3 \%$, unsure mikro yang terkandung didalamnya adalah $\mathrm{Mn}, \mathrm{B}$, $\mathrm{Cu}, \mathrm{Co}$, dan $\mathrm{Zn}$, dengan dosis $2 \mathrm{~g} / \mathrm{l}$ liter air dan diberikan 4 kali dapat memperpanjang umur panen, meningkatkan bobot kering tanaman, meningkatkan bobot segar buah, dan menambah tebal daging buah (Surtinah, 2004).

\section{Metode Penelitian}

Penelitian dilaksanakan di lahan Tlogomas Kecamatan LowokwaruMalang dengan ketinggian tempat \pm 450 dari permukaan laut. Bahan penelitian yang digunakan adalah benih tanaman tomat (Varietas Betavila F1), tanah, pupuk kompos, pupuk kendang sapi, pestisida alami dan pupuk daun seperti Bayfolan dan Gandasil B. Alat yang digunakan adalah, pacul, skop, paranet, sabit dan parang, polibag besar, hand sprayer, cethok, penggaris, ember, gembor, bambu, kertas label, plastik, timbangan analitik, dan kamera. Penelitian menggunakan rancangan acak kelompok (RAK) secara factorial, yang terdiri dari 2 faktor masing-masing: Faktor pertama adalah konsentrasi pupuk daun Gandasil B. K0: 0 (kontrol), K1: 1gr/liter, K2: 2 gr/liter, K3:3 gr/liter. Faktor kedua adalah periode pemupukan P1 : 1minggu, P2 : 2minggu. Terdapat 8 kombinasi perlakuan (K0P1, K1P1,
K2P1，K3P1，K0P2，K1P2, K2P2, dan $\mathrm{K} 3 \mathrm{P} 2$ masing-masing perlakuan di ulang 4 kali terdiri dari 5 sampel tanaman sehingga keseluruhan ada 160 tanaman.

Pemupukan Gandasil B dilakukan setelah tanaman memasuki fase generatif atau setelah tanaman mulai kucup bunga agar merangsang pertumbuhan bunga dan buah. Dosis pupuk daun gandasil B terdiri K0P0 (kontrol) tanpa pemupukan, K1P1 $=1 \mathrm{~g}$ Gandasil B, periode pemupukan 1 minggu; K2P1= $2 \mathrm{~g}$ Gandasil $\mathrm{B}$, periode pemupukan 1 minggu; K3P1 $=3 \mathrm{~g}$ Gandasil B, periode pemupukan 1 minggu; $\mathrm{K} 0 \mathrm{P} 2=$ kontrol, $\mathrm{K} 1 \mathrm{P} 2=1 \mathrm{~g}$ Gandasil B, periode pemupukan 1 minggu; $\mathrm{K} 2 \mathrm{P} 2=2 \mathrm{~g}$ Gandasil $\mathrm{B}$, periode pemupukan 2 minggu; $\mathrm{K} 3 \mathrm{P} 2=3 \mathrm{~g}$ Gandasil B, periode pemupukan 2 minggu. Pengamatan dilakukan pada minggu ke 1 sampai dengan 6 terdiri 5 tanaman sampel dengan parameter: tinggi tanaman dan jumlah daun, saat muncul bunga (hari), jumlah bunga (minggu ke 4 sampai 7), jumlah cabang (minggu ke 4 sampai 6), jumlah buah dan berat buah pada minggu ke 9 sampai 11 .

\section{Hasil dan Pembahasan}

\section{Tinggi Tanaman}

Dosis dan periode pemupukan Gandasil B bernteraksi dalam mendukung pertumbuhan / tinggi tanaman umur 14 dan 49 hari setelah tanam. Pengaruh interaksi dosis dan periode pemupukan Gandasil B disajikan pada Tabel 1. Tabel 1 menunjukkan bahwa pemupukan $2 \mathrm{~g} / 1$ setiap 2 minggu sekali menghasilkan tinggi tanaman tertinggi $(78.24 \mathrm{~cm})$, namun tidak berbeda dengan pemupukan 1 maupun 3 $\mathrm{g} / \mathrm{l}$ per minggu sekali maupun 1-2 $\mathrm{g} / \mathrm{l}$ per 2 minggu sekali. 
Astutik dan A. Sumiati/ Buana Sains Vol 18 No 2 : 149-160

Tabel 1. Pengaruh interaksi Dosis dan Periode Pemupukan Gandasil B Terhadap Tinggi Tanaman.

\begin{tabular}{|c|c|c|}
\hline \multirow{2}{*}{ Perlakuan } & \multicolumn{2}{|c|}{ Tinggi tanaman $(\mathrm{cm})$ pada umur (hari) } \\
\hline & 14 & 49 \\
\hline KOP1 (0 g/1,1 minggu) & $26.91 \mathrm{ab}$ & $72.16 \mathrm{a}$ \\
\hline K1P1 (1g/1/1 Minggu) & $30.33 \mathrm{~b}$ & $76.87 \mathrm{~b}$ \\
\hline K2P1 (2g/l/1Minggu) & $26.20 \mathrm{ab}$ & $71.08 \mathrm{a}$ \\
\hline K3P1(3g/1/1Minggu) & $28.15 \mathrm{~b}$ & $77.49 \mathrm{~b}$ \\
\hline K0P2 (0 g/1,2 minggu) & $27.91 \mathrm{ab}$ & $68.95 \mathrm{a}$ \\
\hline K1P2 (1g/1/2 Minggu) & $25.08 \mathrm{a}$ & $75.70 \mathrm{~b}$ \\
\hline K2P2 (2g/1/2 Minggu) & $27.29 \mathrm{ab}$ & $78.41 \mathrm{~b}$ \\
\hline K3P2 (3g/1/2Minggu) & $27.83 \mathrm{ab}$ & $72.28 \mathrm{a}$ \\
\hline BNT $5 \%$ & 3.04 & 5.73 \\
\hline
\end{tabular}

Keterangan : Angka yang diikuti oleh huruf yang sama pada kolom yang sama menunjukan tidak berbeda nyata pada taraf uji BNT 5\%.

Hal tersebut disebabkan perlakuan konsentrasi pupuk 1 gram dengan periode pemupukan 1 minggu, konsentrasi pupuk 3 gram dengan periode pemupukan 1 minggu, konsentrasi 1 gram dengan periode pemupukan 2 minggu dapat memacu pertumbuhan tinggi tanaman pada umur 49 hst. Seperti yang dikemukakan oleh (Prayitno, 1980) Perlakuan pemupukan dengan berbagai pupuk dan intensitas pemupukan belum menunjukkan pengaruh yang nyata terhadap pertumbuhan vegetatif dan generative.
Namun demikian pertumbuhan generatif tanaman cenderung lebih baik menggunakan Pupuk daun dengan komposisi $\mathrm{P}$ tinggi, seperti gandasil $\mathrm{B}$ dengan kandungan P $20 \%$ dan K $30 \%$ mampu mempercepat pembungaan.

\section{Jumlah Daun}

Dosis dan periode pupuk gandasil B berinteraksi dalam mendukung pertumbuhan jumlah daun. Interaksi antara konsentrasi dan periode pemupukan gandasil B dapat disajikan pada Tabel 2.

Tabel 2. Pengaruh interaksi antara konsentrasi dan priode pemupukan Gandasil B terhadap jumlah daun.

\begin{tabular}{|c|c|c|}
\hline \multirow[b]{2}{*}{ Perlakuan } & \multicolumn{2}{|c|}{ Jumlah Daun Pada Umur (hari) } \\
\hline & 14 & 42 \\
\hline K0P1 (0 g/l, 1 minggu) & $7.74 \mathrm{~b}$ & $16.24 \mathrm{~b}$ \\
\hline K1P1 (1 gr/l,1 minggu) & $7.66 \mathrm{a}$ & $15.41 \mathrm{~b}$ \\
\hline $\mathrm{K} 2 \mathrm{P} 1$ (2 gr/l, $1 \mathrm{minggu})$ & $7.24 \mathrm{a}$ & $16.00 \mathrm{~b}$ \\
\hline $\mathrm{K} 3 \mathrm{P} 1$ (3 gr/l, $1 \mathrm{minggu})$ & $9.66 \mathrm{c}$ & $20.16 \mathrm{c}$ \\
\hline K0P2 (0 g/1, 2 minggu) & $7.41 \mathrm{a}$ & $14.49 \mathrm{a}$ \\
\hline K1P2 (1 gr/1, 2 minggu $)$ & $6.91 \mathrm{a}$ & $15.24 \mathrm{~b}$ \\
\hline K2P2 (2 gr/l, 2 minggu $)$ & $9.08 \mathrm{c}$ & $20.41 \mathrm{c}$ \\
\hline K3P2 (3gr/1, 2 minggu) & $9.66 \mathrm{c}$ & $21.49 \mathrm{c}$ \\
\hline BNT $5 \%$ & 0.75 & 1.29 \\
\hline
\end{tabular}

Keterangan: Angka yang diikuti oleh huruf yang sama pada kolom yang sama menunjukan tidak berbeda nyata pada taraf uji BNT 5\%. 
Jumlah daun terbanyak pada pemupukan Gandasil B $3 \mathrm{~g} / \mathrm{l}$ dengan periode pemupukan per 2 minggu (21.49 helai) tdak berbeda dengan per satu mingggu dan $2 \mathrm{~g} / \mathrm{l}, 2$ minggu, sampai dengan umur umur 42 hari setelah tanam. Hal ini disebabkan semakin tinggi unsur $\mathrm{K}$ maka unsure makro terpenuhi sehingga metabolism berjalan lebih efektif. Roemayanti (2004) menyebutkan bahwa unsur $\mathrm{K}$ berperan penting dalam fotosintesis, dan menguatkan tangkai buah sehingga buah tidak rontok.

Nutrisi yang terkandung dalam pupuk daun gandasil B dapat memenuhi kebutuhan tanaman, pada pertumbuhan daun tanaman tomat membutuhkan unsur kalium $(\mathrm{K})$ dalam jumlah banyak atau besar bila dibandingkan dengan unsur-unsur yang lainya. Oleh karena itu unsur $\mathrm{K}$ harus banyak tersedia pada masa pertumbuhan vegetatif tanaman tomat. Jumlah daun yang dihasilkan dari masingmasing perlakuan sangat berpengaruh terhadap pertumbuhan, karena daun merupakan organ tumbuhan penghasil utama bahan makanan dari hasil fotosintesis selain akar (Dwijoseputro, 1986).
Menurut pendapat Gardner et al., (1991), kekurangan kalium akan memperlihatkan gejalah lemahmya batang, keringnya daun, dan rontoknya bunga maupun buah, serta jumlah buah yang dihasilkan menurun.

Unsur hara merupakan salah satu faktor yang menunjang pertumbuhan dan perkembangan tanaman yang optimal. Penggunaan pupuk sebagai salah satu usaha untuk meningkatkan produksi sawi daging sudah sangat membudaya dan para petani telah menganggap bahwa pupuk dan cara pemupukan sebagai salah satu hal yang tidak dapat dipisahkan dalam kegiatan usaha taninya (Anonim. 2007).

\section{Saat Muncul Bunga}

Tidak terdapat interaksi antara dosis gandasil B dan periode pemupukan terhadap saat muncul bunga, namun dosis Gandasil B berpengaruh pada saat muncul bunga seperti terlihat pada tabel 3. Saat muncul bunga tercepat pada pemupukan Gandasil B $3 \mathrm{~g} / 1$ periode 2 minggu sekali (K3P2) yakni 18 hari setelah tanam.

Tabel 3. Pengaruh Konsentrasi Gandasil B Terhadap Saat Muncul Bunga

\section{Dosis Gandasil (g/l)}

\section{Perlakuan Saat Muncul Bunga (hari)}

\begin{tabular}{ll}
\hline K0 $(0)$ & $20 \mathrm{~b}$ \\
K1 $(1)$ & $20 \mathrm{c}$ \\
K2 $(2)$ & $20 \mathrm{~b}$ \\
K3 $(3)$ & $18 \mathrm{a}$ \\
\hline BNT $5 \%$ & 0.05 \\
\hline
\end{tabular}

Periode Pemupukan (Minggu)

P1 (1) 20

P2 (2) 20

BNT $5 \%$
Keterangan : Angka diikuti oleh huruf yang sama pada kolom yang sama menunjukan tidak berbeda nyata pada taraf uji BNT 5\%. 
Periode pemupukan gandasil B baik seminggu sekali maupun 2 minggu memberikan pengaruh yang tidak berbeda pada pembentukan bunga. Pertumbuhan generatif tanaman cenderung lebih baik menggunakan Pupuk daun dengan komposisi P (fosfor) tinggi, seperti gandasil B mempercepat proses pendewasaan tanaman, sehingga proses pembungaan akan dipercepat (Prayitno, 2000)

Unsur mikro yang terkandung didalam masing - masing pupuk pupuk daun cukup lengkap yaitu $\mathrm{Fe}, \mathrm{Cu}, \mathrm{Zn}$, $\mathrm{Mn}, \mathrm{Mg}, \mathrm{Mo}, \mathrm{Co}, \mathrm{B}$, dan S. Unsur mikro tersebut cukup penting peranannya didalam menunjang proses pertumbuhan vegetatif dan generatif tanaman. Kekurangan $\mathrm{Fe}$ dan $\mathrm{Mn}$ menunjukkan gejala yang sama yaitu daun berwarna hijau muda didaerah tulang - tulang daun. Daun menjadi lebih kecil ukurannya dan mudah gugur. Unsur mikro yang mempengaruhi proses pembungaan, pembuaahan, metabolism N, penyerapam garamgaram, penyerapan hormon - hormon dan beberapa proses metabolism lain adalah Boron ( B ).

Pupuk daun gandasil B mengandung unsur fosfor yang berguna untuk merangsang pertumbuhan akar, selain itu berfungsi sebagai bahan mentah untuk pembentukan sejumlah protein tertentu, mempercepat pembungaan, pemasakan biji dan buah (Lingga, 2008)

Saat muncul bunga berkaitan erat dengan pemenuhan unsur hara terutama unsur phospat (P) yang berfungsi untuk mendorong tanaman masuk ke fase generatif. Fase generatif ditandai dengan terbentuknya primordial bunga dan berkembang menjadi bunga yang siap mengadakan penyerbukan (Yunus dan Tri Haryanto, 1986). Pembungaan merupakan masa transisi tanaman dari fase vegetatif menuju fase generatif yaitu dengan terbentuknya kuncup-kuncup bunga. Pada umumnya proses fisiologis dan morfologis yang mengarah fotoperiode (panjang hari) dan temperatur (Gardner, et al., 1991).

\section{Jumlah Bunga}

Tidak terdapat interaksi antar konsentrasi dan periode pemberian pupuk gandasil B terhadap jumlah bunga pada umur 28, 35 dan 42 hari namun umur 49 hri berinteraksi. Secara terpisah konsentrasi Gandasil B berpengaruh terhadap jumlah bunga.

Tabel 4 Menunjukkan bahwa Jumlah bunga terbanyak terdapat pada konsentrasi (K3P3) dengan rata - rata 10.37 tangkai. Hal ini membuktikan kandungan hara yang terdapat pada konsentrasi 3 gram sangat cepat memacu munculnya bunga. Perlakuan pemupukan dengan berbagai pupuk dan intensitas pemupukan belum menunjukkan pengaruh yang nyata terhadap pertumbuhan vegetatif dan generatif, Namun demikian pertumbuhan generatif tanaman cenderung lebih baik menggunakan Pupuk daun dengan komposisi $\mathrm{P}$ (fosfor) tinggi, seperti gandasil B mempercepat proses pendewasaan tanaman, sehingga proses pembungaan akan dipercepat (Prayitno, 1980)

Menurut Lingga (2003), dalam penggunaan pupuk cair utamanya yang disemprotkan melalui daun, ada beberapa hal yang perlu diperhatikan selain jenis pupuk daun yang digiunakan, kandungan hara pupuk dan konsentrasi larutan yang diberikan, juga waktu penyemprotan.

Tabel 5 menunjukkan bahwa umur 49 hari setelah tanam pada konsentrasi K3P1 jumlah bunga terbanyak dengan rata - rata 8.83 dan 
K2P2 dengan rata - rata 8.74. Hal ini disebabkan karena kandungan unsur Phospat (P) pada pupuk daun gandasil $B$ lebih efisien yang diserap tanaman sehingga tidak kelebihan unsur atau kekurangan unsur tersebut sehingga tepat digunakan untuk menunjang pertumbuhan bunga. Pemenuhan unsur hara terutama unsur phospat (P) yang berfungsi untuk mendorong tanaman masuk ke fase generatif. Fase generatif ditandai dengan terbentuknya primordial bunga dan berkembang menjadi bunga yang siap mengadakan penyerbukan (Yunus dan Tri Haryanto, 1986).

Menurut Novizan (2002), pengaruh pemberian unsure Kalium (K) yang berlebihan menyebabkan menurunnya pertumbuhan tanaman, karena serapan dan translokasi dari kation yang berperan dalam kegiatan fotosintesis menjadi terhambat dan berakibat menurunnya hasil fotosintesis.
Unsur mikro yang terkandung didalam masing - masing pupuk pupuk daun cukup lengkap yaitu $\mathrm{Fe}, \mathrm{Cu}, \mathrm{Zn}$, $\mathrm{Mn}, \mathrm{Mg}, \mathrm{Mo}, \mathrm{Co}, \mathrm{B}$, dan S. Unsur mikro tersebut cukup penting peranannya didalam menunjang proses pertumbuhan vegetatif dan generatif tanaman. Kekurangan $\mathrm{Fe}$ dan $\mathrm{Mn}$ menunjukkan gejala yang sama yaitu daun berwarna hijau muda didaerah tulang - tulang daun. Daun menjadi lebih kecil ukurannya dan mudah gugur. Unsur mikro yang mempengaruhi proses pembungaan, pembuaahan, metabolism N, penyerapam garam garam, penyerapan hormon - hormon dan beberapa proses metabolism lain adalah Boron (B) (Gunawan, 1989).

Menurut pendapat Gardner et al., (1991), yang mengemukakan bahwa kekurangan kalium akan memperlihatkan gejalah lemahmya batang, keringnya daun, dan rontoknya bunga maupun buah, serta jumlah buah yang dihasilkan menurun.

Tabel 4. Pengaruh Konsentrasi Gandasil B Terhadap Jumlah Bunga

\begin{tabular}{lccc}
\hline \multirow{2}{*}{ Perlakuan } & \multicolumn{3}{c}{ Jumlah Bunga pada Umur (hari) } \\
\cline { 2 - 4 } Konsentrasi Gandasil B (g/l) & 28 & 35 & 42 \\
K0 (0) & $4.66 \mathrm{a}$ & $3.91 \mathrm{a}$ & $5.07 \mathrm{a}$ \\
K1 (1) & $5.70 \mathrm{ab}$ & $3.91 \mathrm{a}$ & $6.99 \mathrm{~b}$ \\
K2 (2) & $6.37 \mathrm{~b}$ & $4.53 \mathrm{~b}$ & $6.99 \mathrm{~b}$ \\
K3 (3) & $9.19 \mathrm{c}$ & $10.37 \mathrm{c}$ & $8.74 \mathrm{c}$ \\
\hline BNT 5\% & 1.18 & 0.57 & 1.51 \\
\hline Periode pemupukan (1 minggu) & & & \\
P1 (1) & 6.57 & 5.88 & 6.70 \\
P2 (2) & 6.39 & 5.47 & 7.20 \\
\hline BNT 5\% & TN & TN & TN \\
\hline KN
\end{tabular}

Keterangan : Angka yang diikuti oleh huruf yang sama pada kolom yang sama menunjukan tidak berbeda nyata pada taraf uji BNT 5\%. 
Tabel 5. Pengaruh Interaksi Gandasil B Terhadap Jumlah Bunga pada umur 49 hari Perlakuan Jumlah Bunga pada Umur 49 hari

\begin{tabular}{lc}
\hline K0P1 (0 g/l,1 minggu) & $3.33 \mathrm{a}$ \\
K1P1 (1 gr/l/1 minggu) & $5.83 \mathrm{~b}$ \\
K2P1 (2 gr/l/1 minggu) & $4.91 \mathrm{a}$ \\
K3P1 (3 gr/1/1 minggu) & $8.83 \mathrm{c}$ \\
K0P2(0 g/1,2 minggu $)$ & $3.41 \mathrm{a}$ \\
K1P2 (1 gr/1/2 minggu $)$ & $5.74 \mathrm{~b}$ \\
K2P2 (2 gr/1/2 minggu) & $8.74 \mathrm{c}$ \\
K3P2 (3gr/1/2 minggu) & $5.24 \mathrm{ab}$ \\
\hline BNT 5 \% & 2.24 \\
\hline
\end{tabular}

Keterangan : Angka rerata diikuti oleh huruf yang sama pada kolom yang sama menunjukan tidak berbeda nyata pada taraf uji BNT 5\%.

\section{Jumlah Cabang}

Terdapat interaksi pada perlakuan konsentrasi dan periode pemberian pupuk Gandasil B terhadap jumlah cabang pada umur 49 hari setelah tanam. dapat disajikan pada Tabel 6. Tabel 6 menunjukkan umur 49 hari setelah tanaman pada konsentrasi (K2P2) menghasilkan jumlah cabang terbanyak (7.24). Namun tidak berbeda dengan konsentrasi (K3P1). Hal ini sesuai dengan pendapat Novizan, (2002), menyatakan bahwa untuk memperoleh pertumbuhan dan produksi yang optimum maka hara dalam tanah harus tersedia bagi tanaman, terutama unsur Phospat (P) dam jumlah yang cukup dan berimbang sesuai dengan kebutuhan tanaman dalam bentuk dan dapat diserap oleh system perakaran. Sedangkan pada umur 35 hari setelah tanam tidak menunjukan adanya pengaruh nyata terhadap jumlah cabang hal ini disebabkan kurangnya unsur phospat yang tersedia bagi tanaman sehingga pertumbuhan tanaman terganggu.

Tabel 6. Pengaruh Interaksi Gandasil B Pada Jumlah Cabang

Perlakuan Jumlah Cabang pada Umur 49 hari

\begin{tabular}{lc}
\hline K0P1 (0 g/l,1 minggu) & $4.91 \mathrm{~b}$ \\
K1P1 (1 gr/1/1 minggu $)$ & $4.66 \mathrm{ab}$ \\
K2P1 (2 gr/1/1 minggu) & $4.91 \mathrm{~b}$ \\
K3P1 (3 gr/1/1 minggu) & $7.16 \mathrm{c}$ \\
K0P1 (0 g/1,2 minggu) & $4.33 \mathrm{ab}$ \\
K1P2 (1 gr/1/2 minggu $)$ & $3.91 \mathrm{a}$ \\
K2P2 (2 gr/1/2 minggu) & $7.24 \mathrm{c}$ \\
K3P2 (3gr/1/2 minggu) & $4.49 \mathrm{ab}$ \\
\hline BNT 5 \% & 0.59
\end{tabular}

Keterangan : Angka yang diikuti oleh huruf yang sama pada kolom yang sama menunjukan tidak berbeda nyata pada taraf uji BNT 5\%. 
Hal ini sejalan dengan pendapat Siswandi (2006), yang menyatakan bahwa kekurangan unsur hara Phospat dapat mengakibatkan gangguan pada metabolisme dan perkembangan tanaman, diantaranya menghambat pertumbuhan, kekurangan unsur hara phospat pada tanaman dapat dicirikan dengan pertumbuhan terhambat seperti tidak bertambahnya jumlah cabang.

Menurut Komarayati (2002) menyatakan bahwa apabila tanaman kekurangan unsur hara $\mathrm{P}$, maka tanaman tidak mampu menyerap unsur hara lain dalam jumlah cukup, karena keseimbangan hara dalam tanah akan terganggu. Unsur hara $\mathrm{P}$ berperan dalam mengendalikan proses-proses fisiologi tanaman.

Kandungan unsur Phospat (P) pada pupuk daun gandasil $B$ lebih efisien yang diserap tanaman sehingga tidak kelebihan unsur atau kekurangan unsur tersebut sehingga tepat digunakan untuk menunjang pertumbuhan bunga. Pemenuhan unsur hara terutama unsur phospat (P) yang berfungsi untuk mendorong tanaman masuk ke fase generatif.

\section{Jumlah Total Buah Panen}

Terdapat interaksi antara konsentrasi dengan periode pemberian pupuk gandasil B pada total jumlah buah seperti yang terlihat pada tabel 7 .

Tabel 7 menunjukan bahwa pemberian gandasil B pada konsentrasi (2 gram /liter per 2 minggu) (K2P2) menghasilkan jumlah buah terbanyak yakni 25.98 buah. Hal ini disebabkan unsur Kalium $(\mathrm{K})$ yang terkadung pada pupuk daun Gandasil B optimal atau dosis yang sesuai dengan kebutuhan tanaman maka tanaman dapat menghasilkan jumlah buah pertanaman yang lebih banyak. Hal ini sesuai dengan penjelasan Sutejo (2002), bahwa kalium mempunyai peranan penting bagi tanaman karena kalium membantu proses fotosintesis terutama untuk mengatur pembukaan stomata sehingga $\mathrm{CO}_{2}$ dan $\mathrm{O}_{2}$ dapat masuk ke daun. Kalium sering disebut unsur mutu untuk produksi tanaman. Hal ini kalium lebih mengarah pada mutu hasil suatu tanaman

Tabel 7. Pengaruh Interaksi konsentrasi dan periode pemupukan Gandasil B Terhadap Jumlah Buah

Perlakuan Jumlah Buah

\begin{tabular}{|c|c|}
\hline K0P1 (0 g/l,1 minggu) & $48.25 \mathrm{~b}$ \\
\hline K1P1 (1 gr/l/1 minggu) & $58.75 \mathrm{~b}$ \\
\hline K2P1 (2 gr/l/1 minggu) & $51.75 \mathrm{~b}$ \\
\hline K3P1 (3 gr/l/1 minggu) & $55.75 \mathrm{~b}$ \\
\hline K0P1 (0 g/1,2 minggu) & $40.25 \mathrm{a}$ \\
\hline K1P2 (1 gr/l/2 minggu) & $55.00 \mathrm{~b}$ \\
\hline K2P2 (2 gr/l/2 minggu) & $25.98 \mathrm{c}$ \\
\hline K3P2 (3gr/l/2 minggu) & $59,50 \mathrm{~b}$ \\
\hline
\end{tabular}

Keterangan : Angka yang diikuti oleh huruf sama pada kolom yang sama menunjukan tidak berbeda nyata pada taraf uji BNT 5\%. 
Selain unsur kalium $(K)$ yang terkandung dalam pupuk daun Gandasil B unsur Phospat (P) juga dibutuhkan oleh tanaman sayuran terutama jenis sayuran yang dimanfaatkan buahnya termasuk tanaman tomat, karena phospat $(\mathrm{P})$ merupakan unsur pokok pada fase generatif khusus untuk pembentuk pembentukan bunga, buah dan biji. Hal ini sesuai dengan penjelasan Reinsema, (2000) pada tomat, bahwa penggunaan unsur hara Phospat $(\mathrm{P})$ pada tanaman tomat dapat mendorong terbentuknya bunga dan buah. Unsur phospat sering terjadi kekurangan didalam tanah akibat jumlah unsur Phospat didalam tanah sedikit, sebagian besar tidak dapat diambil tanaman, dan sering terjadi fiksasi oleh $\mathrm{Al}$ pada tanah masam atau oleh Ca pada tanah alkalis (Syarief, 1986).

Unsur mikro yang terkandung didalam masing - masing pupuk pupuk daun cukup lengkap yaitu $\mathrm{Fe}, \mathrm{Cu}, \mathrm{Zn}$,
$\mathrm{Mn}, \mathrm{Mg}, \mathrm{Mo}, \mathrm{Co}, \mathrm{B}$, dan S. Unsur mikro tersebut cukup penting peranannya didalam menunjang proses pertumbuhan vegetatif dan generatif tanaman. Kekurangan $\mathrm{Fe}$ dan $\mathrm{Mn}$ menunjukkan gejala yang sama yaitu daun berwarna hijau muda didaerah tulang - tulang daun. Daun menjadi lebih kecil ukurannya dan mudah gugur. Unsur mikro yang mempengaruhi proses pembungaan, pembuaahan, metabolism N, penyerapam garam garam, penyerapan hormon - hormon dan beberapa proses metabolism lain adalah Boron ( B ) (Gunawan, 1989).

\section{Berat Buah Panen}

Tidak terdapat interaksi antara konsentrasi dengan periode pemberian pupuk Gandasil B terhadap berat buah panen. Namun secara terpisah konsentrasi Gandasil B berpengaruh terhadap berat buah hasil panen seperti terlihat pada tabel 8 .

Tabel 8 Pengaruh Gandasil B Terhadap Berat Buah

Perlakuan Berat Buah (g)

Konsentrasi Gandasil B (g/l

K0 (0) $\quad 692.07 \mathrm{a}$

K1 (1) $1096.44 \mathrm{ab}$

K2 (2) $1232.84 \mathrm{~b}$

K3 (3) 1084.99 a

BNT 5\% 153.66

Periode pemupukan (minggu)

P1 (1)

P2 (2)

1072.27

BNT 5\%

TN

Keterangan : Angka yang diikuti oleh huruf yang sama pada kolom yang sama menunjukan tidak berbeda nyata pada taraf uji BNT 5\%. 
Tabel 8 menunjukan bahwa pada konsentrasi 2gram/liter (K2) menghasilkan berat buah terbanyak yakni 1232.84 b g. Menurut pendapat Gardner et al., (1991), yang mengemukakan bahwa kekurangan kalium akan memperlihatkan gejalah lemahmya batang, keringnya daun, dan rontoknya bunga maupun buah, serta jumlah buah yang dihasilkan menurun.

Selain unsur kalium (K) yang terkandung dalam pupuk daun Gandasil B unsur Phospat (P) juga dibutuhkan oleh tanaman sayuran terutama jenis sayuran yang dimanfaatkan buahnya termasuk tanaman tomat, karena phospat (P) merupakan unsur pokok pada fase generatif khusus untuk pembentuk pembentukan bunga, buah dan biji. Hal ini sesuai dengan penjelasan Reinsema, (2000) pada tomat, bahwa penggunaan unsur hara Phospat (P) pada tanaman tomat dapat mendorong terbentuknya bunga dan buah. Unsur phospat sering terjadi kekurangan didalam tanah akibat jumlah unsur Phospat didalam tanah sedikit, sebagian besar tidak dapat diambil tanaman, dan sering terjadi fiksasi oleh $\mathrm{Al}$ pada tanah masam atau oleh Ca pada tanah alkalis (Syarief, 1986). Adanya peningkatan suplai unsur hara yang digunakan untuk memenuhi kebutuhan tanaman dapat menyebabkan produktivitas tanaman yang optimal. Hasil tanaman dipengaruhi oleh unsur hara nitrogen, fosfor dan kalium yang diberikan. Kekurangan atau kelebihan salah satu unsur tersebut dapat menurunkan hasil tanaman.

\section{Kesimpulan}

Hasil penelitian dapat disimpulkan bahwa terdapat interaksi antara konsentrasi dengan periode pemupukan Gandasil B terhadap parameter pertumbuhan tinggi tanaman umur 49 hari, jumlah daun pada umur 14, 21, 28, 35, dan 42 hari, Jumlah bunga pada umur 49 hari, Jumlah cabang pada umur 49 hari, dan total buah. Gandasil B dosis $2 \mathrm{~g} / \mathrm{l}$ juga mampu menghasilkan berat buah terbaik (1,23 $\mathrm{kg} /$ tanaman)

\section{Daftar Pustaka}

BPS, 2012. Produksi Tomat diindonesia Mulai tahun 2000 sampai perlindungan hasil panen. FF Wardani.

Cahyono, I. 2008. Tomat : Usaha Tani dan Penanganan Pasca Panen, Kanisius, Yogyakarta.

Gardner, F. D.,R. B. Pearce dan R. L., Mitchell. 1985. Physiology of Crops Plants lowa State Univercity Pres Ames, USA.

Haindita, N. 2008. Analisis Ekspor Tomat Segar Indonesia, Ringkasan Eksekutif, Institut Pertanian Bogor.

Lingga, P. 2003. Petunjuk Penggunaan

Pupuk. Penebar Swadaya. Jakarta.

Novizan. 2002. Petunjuk Pemupukan yang Efektif. Agro Media Pustaka. Jakarta.

Prayitno, 2000. Pengaruh Beberapa Macam Pupuk Daun terhadap Pertumbuhan Anggrek Vanda Hibrida.

Rinsema. 2000. Pupuk dan Cara

Pemupukan. Bharatara Karya Aksara, Jakarta.

Rosmarkam, A. dan N.W. Yuwono. 2002. Ilmu Kesuburan Tanah. Kanisius. Yogyakarta.

Sabiham, S. 2006. Prinsip-Prinsip Dasar Uji Tanah dalam Pelatihan Optimalisas dalam Pemupukan. Proyek Pembinaan Kelembagaan Litbang Pertanian Bekerjasama dengan Faperta, IPB, Bogor. 
Surtinah 2004. Pengaruh Cenkaman Air pada fase Tumbuh geeneratif dan Pemberian Pupuk Gandasil B terhadap kualitas buah melon (cucumis melo L ). XIX : $3 \mathrm{~J}$. Dinamika Pertanian : 325 - 335.

Sutanto, R. 1998. Kesuburan Tanah Sebagai Landasan Pertanian Lestari. Makalah Seminar Paguyuban Tani HPS Seluruh Indonesia. Ambarawa. 